RESEARCH ARTICLE

\title{
A Study on Awareness and Adoption of Climate Resilient Farm Technologies on Crop Production and Protection in Namakkal District of Tamil Nadu
}

\author{
S. Kathiresan ${ }^{1}$ and T. Raj Pravin ${ }^{2 *}$ \\ ${ }^{1}$ Department of Agricultural Extension, Faculty of Agriculture, Annamalai University, Annamalai Nagar - 608 002 , Tamil Nadu, India \\ ${ }^{2 *}$ Department of Agricultural Extension, Faculty of Agriculture, Annamalai University, Annamalai Nagar - 608 002 , Tamil Nadu, India
}

\begin{abstract}
Climate change issues are affecting the lives and livelihoods of the farming community in our state. With majority of our rural population dependent on farming, the need of the hour is to create awareness among farmers on climate-resilient farm technologies and make them adopt them. So, a study was conducted in the Erumapatty block of Namakkal district of Tamil Nadu to study the awareness and adoption of climate-resilient farm technologies. The findings of this study revealed that majority of the respondents (68.33 per cent) had high level of awareness on climate-resilient farm technologies. With regard to adoption, majority (60.00 per cent) had medium level of adoption on climate-resilient farm technologies. On crop production and protection climate resilient farm technologies, namely drought-resilient varieties, Intercropping, Identification and use of short-duration varieties, drought-resilient fodder crops, Community nursery as a contingency measure for delayed planting, IPDM and PPFM to combat drought condition in small onion majority of the farmers in the study area are aware of it and adopt it in this study area.
\end{abstract}

Keywords: Climate-resilient farm technologies; Awareness; Adoption

\section{INTRODUCTION}

Climate remains the foremost factor for doing farming and rainfall plays a significant role in agriculture. The present climate change-related issues like prolonged droughts, aberrant rainfall, floods and cyclones, changes in diurnal variations of temperature are affecting the production, productivity and livelihoods of small and marginal farmers, farm laborers creating a negative impact on the economy of our nation. With climate change issues becoming the new normal, avoidance of climate variability is not possible. Hence there arises a need for creating awareness and adoption of climate-resilient farm technologies among the farming community suited to the livelihood needs of the farming community. Keeping this in view, a study was undertaken to assess the awareness and adoption of climate-resilient farm technologies in crop production and protection in Namakkal district of Tamil Nadu.

\section{RESEARCH METHODOLOGY}

The study was undertaken in the Namakkal district of Tamil Nadu, which is prone to frequent natural vagaries as a result of climate change-related issues. Moreover, the National Initiative on Climate Resilient
Agriculture (NICRA) scheme was also initiated in Namakkal, and the successful introduction of many climate-resilient farm technologies is supposed to assist our farming community facing many climate adversities. Erumapatty block was purposively selected as it was successfully implementing many NICRA initiatives under different modules. Among the 24 village panchayats in Erumapatty block, Vadavathur village panchayat was selected for this study as meteorological observations reveal the presence of frequent natural vagaries as a result of very less rainfall of $400 \mathrm{~mm}$. About 120 farm respondents who are beneficiaries of NICRA scheme and are mostly fodder crop cultivators was selected for this study. A pre-tested interview schedule was used for collecting the data and appropriate statistical tools was used for its analysis.

\section{FINDINGS AND DISCUSSION}

The findings of the study are given below.

\section{Overall awareness of farmers on climate- resilient farm technologies}

Awareness is a foremost factor for the adoption of innovations. Without adequate awareness, adoption will not be possible. Nowadays, climatic 
variability is a big issue in farming and it affects the production, productivity and livelihood of many of our farmers. So, the farmers must be aware of climate resilient farm technologies and know how to cope with climate change issues. In this study area, the major climatic vulnerability is 'drought.' So, the drought-related climate-resilient farm technologies were identified and their awareness measured. The results are given in table-1.

Table 1. Distribution of the respondents according to their overall awareness of climate resilient farm technologies $(n=120)$

\begin{tabular}{lrr}
\hline \multicolumn{1}{c}{ Category } & Number & \multicolumn{2}{c}{ Percentage } \\
\hline Low (53 to 57) & 6 & 5.00 \\
Medium (58 to 61) & 32 & 26.67 \\
High (62 to 66) & 82 & 68.33 \\
Total & 120 & 100.00 \\
\hline
\end{tabular}

It could be observed from the above table-1 that more than half (68.33 per cent) of the farmers had high level of awareness, followed by medium ( 26.67 per cent) and low (5.00 per cent) level of awareness about climate-resilient farm technologies. The high level of awareness in this study area is due to the new farm interventions made through NICRA scheme initiated by ICAR-Krishi Vigyan Kendra of TANUVAS at Vadavathur village. Many climate-resilient farm technologies were introduced and demonstrated by Krishi Vigyan Kendra (KVK) scientists and extension workers. This finding derives support from Onyegbula (2017) and Maka et al., (2019).

\section{Overall adoption of farmers on climate-resilient farm technologies}

Adoption is a decision to make full use of innovations as the best course of action available. The main motive of the introduction of improved farm technologies is to achieve a higher adoption rate. The data has been collected about the level of adoption of climate-resilient farm technologies and has been presented in below table- 2 .

Table 2. Distribution of the respondents according to their overall adoption of climateresilient farm technologies $(n=120)$

\begin{tabular}{lrr}
\hline Category & Number & Percentage \\
\hline Low (45 to 51) & 10 & 8.33 \\
Medium (52 to 57) & 72 & 60.00 \\
High (58 to 63) & 38 & 31.67 \\
& 120 & 100.00 \\
\hline
\end{tabular}

It could be observed from the above table-2 that majority (60.00 per cent) of the farmers had medium level of adoption followed by high (31.67 per cent) and low (8.33 per cent) level of adoption on climate resilient farm technologies. The medium level of adoption in this study area might be due to resource constraints of small and marginal farmers in the study area. Moreover, in few cases the nature of farmer land holdings, crops cultivated and farm size also prevent them from adopting many climateresilient farm technologies. These findings are in line with Tanusri (2015) and Oraon et al (2018).

\section{Awareness and Adoption of Climate Resilient Farm Technologies on Crop Production and Protection}

The findings of the study on awareness and adoption of climate-resilient farm technologies on Crop production and protection are presented in Table 3.

Table 3. Distribution of respondents according to their technology wise awareness and adoption on climate resilient farm technologies on Crop production and protection $(n=120)$

\begin{tabular}{|c|c|c|c|c|}
\hline \multirow{2}{*}{$\begin{array}{c}\text { Climate-resilient farm } \\
\text { technologies }\end{array}$} & \multicolumn{2}{|c|}{ Awareness } & \multicolumn{2}{|c|}{ Adoption } \\
\hline & No. & $\%$ & No. & $\%$ \\
\hline $\begin{array}{l}\text { Use of drought resilient } \\
\text { varieties }\end{array}$ & 120 & 100 & 120 & 100 \\
\hline Intercropping & 116 & 96.66 & 90 & 75 \\
\hline $\begin{array}{l}\text { Identification and use of } \\
\text { short duration varieties }\end{array}$ & 112 & 93.33 & 98 & 81.66 \\
\hline $\begin{array}{l}\text { Drought resilient fodder } \\
\text { crops }\end{array}$ & 120 & 100 & 112 & 93.33 \\
\hline $\begin{array}{l}\text { Crop diversification for } \\
\text { livelihood security and } \\
\text { resilience to climate } \\
\text { variability }\end{array}$ & 110 & 91.66 & 80 & 66.66 \\
\hline $\begin{array}{l}\text { Community nursery as a } \\
\text { contingency measure for } \\
\text { delayed planting }\end{array}$ & 120 & 100 & 120 & 100 \\
\hline $\begin{array}{l}\text { Integrated Pest and } \\
\text { Disease Management } \\
\text { (IPDM) practices in small } \\
\text { onion }\end{array}$ & 120 & 100 & 108 & 90 \\
\hline $\begin{array}{l}\text { Foliar spray of (Pink } \\
\text { Pigmented Facultative } \\
\text { Methylotrophs (PPFM) to } \\
\text { combat drought condition in } \\
\text { small onion }\end{array}$ & 116 & 96.66 & 106 & 88.33 \\
\hline
\end{tabular}

Crop production and protection climate-resilient farm technologies consist of Use of droughtresilient varieties, Intercropping, Identification and use of short-duration varieties, Cultivation of drought resilient fodder crops, Crop diversification for livelihood security and resilience to climate variability, Community nursery as a contingency measure for delayed planting, Integrated Pest and Disease Management (IPDM) practices in small onion and Foliar spray of (Pink Pigmented Facultative Methylotrophs (PPFM) to combat drought condition in small onion in this study area.

\section{Use of drought resilient varieties}

It could be seen from the table-3 that about cent per cent of the farmers were aware about droughtresilient varieties in this study area and all farmers have adopted this climate-resilient farm technology. The reason might be due to the awareness and frequent demonstrations conducted by ICAR-KVK through NICRA scheme. Under NICRA scheme, KVK 
had demonstrated the following drought-resilient varieties of Sorghum, Black gram, Green gram, Red gram, Groundnut and Castor for cultivation. They are listed below in table-4.

Table 4: Drought resilient varieties demonstrated by KVK through NICRA scheme at the study area in Namakkal district

\begin{tabular}{ll}
\hline Crop & Varieties \\
\hline Sorghum & CO-30, K.8, APK-1 \& Payur 2 \\
Black gram & CO-6, VBN-6 \& MDU-1 \\
Green gram & VBN-3 \& CO-8 \\
Red gram & CO-7, VBN-2 \& VBN-6 \\
Groundnut & TMV-7, TMV-13, K-6 \& CO-6 \\
Castor & YRCH-1 \& DCH-177 \\
Red gram + Groundnut & CO(RG) 7 \\
\hline
\end{tabular}

\section{Intercropping}

It could be seen from the table- 3 that about 96.66 per cent of the farmers were aware about benefits of intercropping and 75.00 per cent of the farmers had adopted this climate-resilient farm technology to get more farm produce and gain remuneration through its cultivation. The reason might be due to the high level of awareness created through NICRA interventions in this study area. The farmers in study village are cultivating groundnut intercropped with red gram [CO(RG)7] to cope up with frequent drought and also gain more farm remuneration.

\section{Identification and use of short-duration varieties}

It could be seen from the table- 3 that about 93.33 per cent of the farmers were aware about short-duration varieties and 81.66 per cent of the farmers have adopted this climate-resilient farm technology over existing varieties. New short-duration, synchronized maturity varieties on Black gram, Green gram and Red gram has been introduced and demonstrated by KVK through NICRA scheme in this study area and are found to be resistant to Yellow Mosaic Virus widely prevalent in the study area. This is the possible reason for the adoption of many short-duration varieties in the study area with increased yields on raising pulse crops.

Table 5. Introduction of new short duration, synchronized maturity varieties of pulse crops by KVK at the study area in Namakkal district

\begin{tabular}{|c|c|c|}
\hline Crop & Existing variety & $\begin{array}{c}\text { New short- } \\
\text { duration varieties }\end{array}$ \\
\hline Black gram & T-9 & CO-6 \\
\hline Green gram & CO-6 & VBN-3 \\
\hline Red gram & Long duration variety (180 days) & $\mathrm{CO}(\mathrm{RG}) 7$ \\
\hline
\end{tabular}

\section{Drought resilient fodder crops}

It could be seen from the Table 3 that about cent per cent of the farmers were aware of raising drought-resilient fodder crops and 93.33 per cent of the farmers adopted its cultivation. The reason might be due to majority of farmers rearing farm animals and are in need for drought-resistant fodder crops to reduce their milk production cost during times of natural vagaries. After NICRA intervention, the farmers had cultivated this new fodder varieties over traditional varieties, which resulted in higher yields also.

Table 6. Drought resilient fodder varieties demonstrated by KVK through NICRA scheme at the study area in Namakkal district

\begin{tabular}{lll}
\hline Fodder & Existing variety & $\begin{array}{l}\text { New high } \\
\text { yielding variety }\end{array}$ \\
\hline Sorghum & CO-4 & $\begin{array}{l}\mathrm{K}-8, \text { APK-1 \& } \\
\text { CO-30 }\end{array}$ \\
Fodder sorghum & Red sorghum (local variety) & CoFS-29 \\
Cumbu Napier grass & CO-2, CO-3 & $\begin{array}{l}\text { CO-4ybrid } \\
\text { grass) }\end{array}$ \\
\hline
\end{tabular}

\section{Crop diversification for livelihood security and} resilience to climate variability

The data from table-3 reveal that about 91.66 per cent of the farmers were aware about crop diversification for their livelihood security and 66.66 per cent of the farmers adopted this climateresilient farm technology. The farmers have gained awareness about crop diversification through NICRA scheme. Small onion, Ground nut and Pulses are the main crops cultivated in the study area, which are mostly affected due to the late onset of monsoon followed by dry spell at critical crop growth stages. So, they are presently moving to crop diversification of onion with Jasmine. Jasmine as a perennial crop is little bit resistant to drought. It has emerged as an alternative source of livelihood for small and marginal farmers in this study village. They were cultivating Jasmine var. Ramanathapuram Gundu Malligai which fetches them higher yield and profits

\section{Community nursery as a contingency measure for delayed planting}

It could be seen from the table-3 that about cent per cent of the farmers were aware about community nursery and all of them adopt this climate-resilient farm technology. After NICRA intervention, the KVK has established the community small onion nursery in Vadavathur village on pilot basis for the benefit of farm community. This is the possible reason for adoption of the community nursery technique in the study area. In NICRA villages, Small onion or sambar onion is major crop cultivated in the study area which is main source of income for small and marginal farmers. Due to the delayed onset of monsoon, the sowing gets delayed and it affects their productivity and livelihood of many small and marginal farmers. To solve this issue, the concept of community small onion nursery was introduced and 
farmers has been adopted this climate-resilient farm technology. The State Department of Horticulture is also providing encouragement with a $50 \%$ subsidy to promoting this type of community activities. This has emerged as an important contingency measure for delayed planting.

\section{Integrated Pest and Disease Management (IPDM) practices in small onion}

It could be seen from the table- 3 that about cent per cent of the farmers were aware about IPDM practices in small onion and 90.00 per cent of the farmers have adopted this climate-resilient farm technology. The various Integrated Pest and Diseases Management (IPDM) practices in small onion-like seed treatment with biocontrol agents, border cropping and use of blue sticky traps at less cost and increased returns has made them adopt these new technologies as it is very cost-effective, eco-friendly in nature and gives them handsome profits.

\section{Foliar spray of Pink Pigmented Facultative Methylotrophs (PPFM) to combat drought condition in small onion}

It could be seen from the table- 3 that about 96.66 per cent of the farmers were aware about the foliar spray of PPFM and 88.33 per cent of the farmers adopted this new technology. The farmers have sprayed Pink Pigmented Facultative Methylotrophs (PPFM) bacteria solution as foliar spray to small onion during bulbing stage as it increases the number of leaf sheath per plant, leaf chlorophyll, bulb number and yield per plant. This simple technology is found to be highly profitable and remunerative to them and is able to combat severe drought situations. This is the possible reason for such an outcome.

\section{SUMMARY AND CONCLUSION}

To conclude, more than half (68.33 per cent) of the farmers in the study area had high level of awareness on climate-resilient farm technologies and majority (60.00 per cent) had medium level on its adoption. The findings on climate-resilient farm technologies on crop production and protection reveal that about cent per cent of the farmers were aware about drought-resilient varieties and all of them adopted it in the study area. About $96.66 \mathrm{per}$ cent of the farmers were aware about intercropping and 75.00 per cent of the farmers had adopted this climate-resilient farm technology. About 93.33 per cent of the farmers were aware about short-duration varieties and 81.66 per cent of the farmers adopted it. About cent per cent of the farmers are aware about fodder crops cultivation and 93.33 per cent of the farmers adopted this climate resilient farm technology. About 91.66 per cent of the farmers were aware about crop diversification and 66.66 per cent of the farmers adopted it. With regard to community nursery, about cent per cent of the farmers were aware of it and all the respondents in the study area have adopted it. In onion cultivation, all farmers were aware about IPDM practices and 90.00 per cent of the farmers adopted this climateresilient farm technology. About 96.66 per cent of the farmers were aware about foliar spray of PPFM and 88.33 per cent of the farmers adopted this climate-resilient farm technology in this study.

\section{REFERENCES}

Kathiresan, S. 2020. Developing new extension strategies for climate change issues in Namakkal district, Unpublished M.Sc., (Ag). Thesis, Annamalai University. Annamalai Nagar.

Maka, L., Ighodaro, I.D. and Ngcobo-Ngotho, G.P.T. 2019. Capacity Development for Scaling up Climate-Smart Agriculture (CSA) Innovations: Agricultural Extension's Role in Mitigating Climate Change Effects in Gqumashe Community, Eastern Cape, South Africa. South African Journal of Agricultural Extension, 47(1): 45-53.

Onyegbula, C.B. 2017. Rice farmers perception of effects of climate change on rice development stage in Niger state, Journal of Agricultural Extension and Rural Development. 9(2): 14-19.

Oraon, D., Singh, RK., Pandey, VK., Rai, VP., Singh, UK and Z. Alam. 2018. Extent of Adoption of Climate Resilient Technologies in Adopted Villages of Chatra District in Jharkhand. Journal of Krishi Vigyan, 7(1): 124-128.

Report on National Initiative on Climate Resilient Agriculture (2011-2016), Smart Practices and Technological Interventions for Climate Resilient Agriculture Demonstrated at Namakkal District, Published by ICAR-KVK, Namakkal - 637002 , PP: 1-80.

Tanusri Dey. 2015. Perception on Effect of Climate Change on Forest and Adaptation trategies of Forest Dependent Communities in a Humid Tropical Foothill Forest of Indian Eastern Himalayas, M.Sc., (forestry), Thesis, Uttar Banga Krishi Viswavidyalaya, West Bengal. 